\title{
Phenotypic Associations Between Traits Other than Production and Longevity in New Zealand Dairy Cattle
}

\author{
D. P. Berry, ${ }^{1}$ B. L. Harris, ${ }^{2}$ A. M. Winkelman, ${ }^{2}$ and W. Montgomerie ${ }^{3}$ \\ ${ }^{1}$ Dairy Production Department, Teagasc, Moorepark Production Research Centre, \\ Fermoy, Co. Cork, Ireland \\ ${ }^{2}$ Livestock Improvement, and \\ ${ }^{3}$ Animal Evaluation Unit, Private Bag 3016, Hamilton, New Zealand
}

\begin{abstract}
A proportional hazards model was used to investigate the phenotypic effect of traits other than production (TOP) on true and functional longevity across purebred and crossbred Holstein-Friesian and Jersey dairy cattle in registered and commercial herds in New Zealand. The hazard function was described as the product of a baseline hazard function and the time-independent effects of age at first calving, heterosis, proportion of breed, period of last calving relative to herdmates, and TOP; a time-dependent effect of herd-year was also included. The influence of TOP on functional longevity was assessed by adjusting true longevity for the timeindependent effects of production values as well as the time-dependent effects of deviation of milk, fat, and protein yield within contemporary group. All analyses were stratified by breed, and separate analyses were carried out for registered or commercial herds. All TOP were significantly related to true and functional longevity. Obvious differences existed in the relative influence of individual TOP on longevity in registered or commercial herds. Of the individual TOP describing the physical characteristics of the cow, the udder-related TOP exhibited the largest influence on functional longevity. Farmer opinion explained the largest proportion of variation in true and functional longevity among cows. In commercial herds, the risk of culling in cows with very low farmer opinion was 1.5 to 2.0 times that in cows with average or high farmer opinion.
\end{abstract}

(Key words: survival analysis, longevity, New Zealand, dairy)

Abbreviation key: AIC = Akaike's information criterion, TOP = traits other than production.

Received December 7, 2004.

Accepted April 12, 2005.

Corresponding author: D. P. Berry; e-mail: dberry@moorepark. teagasc.ie.

\section{INTRODUCTION}

Reduced longevity in dairy cattle is recognized worldwide to be a considerable cost to the dairy industry (Harris et al., 1996; Veerkamp et al., 2002). With improved longevity, the age structure of the herd is altered toward more mature cows that are expected to have higher yields; the opportunity for voluntary culling for low production is also increased. Involuntary replacement rate or cost is reduced, and the overall cost of replacements is amortized over a longer time or production horizon with improved longevity. Because fewer replacements are required, higher selection intensity in dams is possible. The possible benefits of increased longevity generally outweigh the loss in revenue from the salvage value of cull cows and genetic improvement through replacement heifers. However, longevity is a complex quantitative trait influenced by a large number of factors such as the milk production (Dentine et al., 1987), fertility (Dentine et al., 1987; Roxström and Strandberg, 2002), health (Geishauser et al., 1998; Neerhof et al., 2000), and physical characteristics (Cue et al., 1996; Larroque and Ducrocq, 2001; Schneider et al., 2003) of the cow.

Several studies have evaluated the genetic relationships between traits other than production (TOP) and longevity in dairy cattle (Short and Lawlor, 1992; Vollema et al., 2000; Larroque and Ducrocq, 2001). To facilitate a more accurate choice of TOP as predictors of longevity, phenotypic relationships between TOP and longevity are also required (Larroque and Ducrocq, 2001).

Phenotypic relationships between TOP and longevity may be assessed as the ability of the cow to avoid voluntary culling or a combination of voluntary and involuntary culling. Voluntary culling occurs when a farmer makes a conscious decision to cull a healthy, fertile cow on the basis of low milk production. In contrast, involuntary culling occurs when a farmer is forced to cull a potentially profitable cow because of infertility, illness, injury, or death. Van Arendonk (1986) showed that if involuntary culling is decreased, a higher volun- 
tary culling rate could be implemented, resulting in higher profits.

Adjustment of longevity for differences in milk production facilitates the estimation of the relationship between TOP and longevity independent of milk production. The resulting trait has been termed functional longevity (Ducrocq et al., 1988) and refers to the ability of a cow to delay involuntary culling.

Among the individual TOP, the strongest associations with longevity were found with udder traits in US (Short and Lawlor, 1992), Canadian (Dekkers et al., 1994; Schneider et al., 2003), Dutch (Vollema and Groen 1998), German (Buenger et al., 2001), French (Larroque and Ducrocq, 2001), and Spanish (Chirinos et al., 2003) Holstein-Friesian cows. Similar results were found in Jersey cattle in the US (Caraviello et al., 2003).

Reported relationships between feet and leg traits and herd life are less consistent. Some studies (Rogers et al., 1989; Burke and Funk, 1993; Schneider et al., 2003) reported significant relationships between feet and legs and longevity; other studies (Cassell et al., 1990; Larroque and Ducrocq, 2001) reported little or no significant relationship. Burke and Funk (1993) reported a significant difference in the relationship between feet and legs and herd life depending on the system of housing the cow was exposed to. The relative importance of TOP as predictors of longevity also differs between registered and non-registered cows (Cassell et al., 1990; Short and Lawlor, 1992; Larroque and Ducrocq, 2001), especially for the body traits.

Longevity is difficult to quantify and analyze because of the presence of incomplete records (i.e., censored records). Replacing longevity with stayability to a set period of time is not ideal because of the loss of information. Similarly, excluding censored records from the analysis or treating the censored records as complete will lead to biased results. In addition, survival times have a skewed distribution, and the environmental and genetic influences on longevity may change with time, making it inappropriate to use traditional linear models. Survival analysis provides a solution to account for the censored data, the non-normal distribution of longevity, and the changing influence of explanatory variables with time.

The objective of the present study was to assess the phenotypic relationships between TOP and true and functional longevity across purebred and crossbred dairy cattle in registered and commercial New Zealand herds using survival analysis. Dairy farming systems in New Zealand are primarily pasture-based, and up-todate research on the phenotypic relationships between TOP and longevity in pasture-based systems of dairy production is lacking.

\section{MATERIALS AND METHODS}

\section{Traits other than Production}

Data were extracted from the New Zealand national database on all primiparous cows that were classified for TOP throughout years 1987 and 2003. In New Zealand, 17 TOP are assessed: 4 by the dairy farmer and 13 by industry-trained classifiers, primarily from the breed societies. The 4 TOP assessed by the dairy farmer relate to the management of the cow; these include adaptability to the milking routine, speed of milking, temperament, and overall farmer opinion. The remaining 13 inspector-scored TOP relate to the conformation of the cow; these include stature, capacity, rump angle, rump width, legs, live weight, udder support, fore udder attachment, rear udder height, front teat placement, rear teat placement, and 2 composite traits (udder overall and dairy conformation). Dairy conformation in New Zealand refers to all traits pertaining to the dairy conformation of the cow including the body traits that have been scored but excluding all udderrelated traits. Live weight is currently included as a goal trait in the New Zealand national breeding objective (Harris et al., 1996) and, therefore, was not included in the current analysis because of the possible introduction of bias attributable to selection. All TOP are listed in Table 1 and are described in more detail by Cue et al. (1996). All traits were assessed in unit increments from 1 to 9 . Only the first TOP record of the cow in first lactation was retained for inclusion in the analysis; this applied to both management and inspector-scored traits. On average, animals included in the analysis were scored anywhere from 5 to $265 \mathrm{~d}$ of lactation; the average was between 90 and $100 \mathrm{~d}$, and the standard deviation was $33 \mathrm{~d}$. In total, 745,560 primiparous cows had information on TOP.

Contemporary groups were formed as a 3-way interaction among herd, year, and season of calving; season was defined as either spring or autumn calving. A total of 22,927 contemporary groups were formed. Contemporary groups with $<10$ records were removed; 726,520 records from 18,747 herd-year-season contemporary groups remained. Preliminary analysis of the individual TOP data revealed skewness and kurtosis, indicating deviation from a normal distribution. Snell's method (Snell, 1964) was used to compute scores to reduce the departure from normality. The scores were subsequently re-scaled to a scale of 1 to 9 to ease interpretation of the results. Average skewness and kurtosis were reduced by 81 and $15 \%$, respectively, following transformation of the data.

The TOP data (following re-scaling using the Snell transformation) were pre-adjusted for the systematic environmental effects of age at first calving and stage 
Table 1. Snell-transformed (Snell, 1964) means (adjusted for age at calving nested within breed and stage of lactation at assessment) for each trait in registered and commercial herds. All traits were assessed in unit increments on a scale of 1 to 9 .

\begin{tabular}{|c|c|c|c|c|c|c|}
\hline & \multicolumn{2}{|c|}{ Holstein-Friesian } & \multicolumn{2}{|c|}{ Jersey } & \multicolumn{2}{|c|}{ Crossbred } \\
\hline & Registered & Commercial & Registered & Commercial & Registered & Commercial \\
\hline Adaptability & 5.63 & 5.27 & 5.80 & 5.29 & 5.36 & 5.30 \\
\hline Temperament & 5.91 & 5.52 & 6.09 & 5.61 & 5.65 & 5.58 \\
\hline Speed & 5.65 & 5.30 & 5.97 & 5.35 & 5.45 & 5.37 \\
\hline Opinion & 5.87 & 5.56 & 6.18 & 5.72 & 5.69 & 5.65 \\
\hline Stature & 6.70 & 6.32 & 5.87 & 5.84 & 6.25 & 6.12 \\
\hline Capacity & 5.89 & 5.71 & 6.92 & 6.53 & 6.01 & 6.06 \\
\hline Rump angle & 5.08 & 5.25 & 5.35 & 5.50 & 5.24 & 5.33 \\
\hline Rump width & 5.85 & 5.71 & 6.57 & 6.26 & 5.95 & 5.94 \\
\hline Legs & 5.72 & 5.73 & 5.50 & 5.59 & 5.71 & 5.69 \\
\hline Fore udder attachment & 5.16 & 4.89 & 5.67 & 5.16 & 5.08 & 5.04 \\
\hline Udder support & 5.16 & 4.94 & 5.60 & 5.08 & 5.08 & 5.04 \\
\hline Rear udder height & 5.06 & 4.77 & 5.55 & 4.91 & 4.96 & 4.90 \\
\hline Front teat placement & 4.72 & 4.57 & 4.51 & 4.55 & 4.61 & 4.58 \\
\hline Rear teat placement & 6.07 & 5.90 & 5.54 & 5.63 & 5.91 & 5.80 \\
\hline Udder overall & 4.93 & 4.65 & 5.30 & 4.79 & 4.80 & 4.76 \\
\hline Dairy conformation & 5.67 & 5.47 & 6.53 & 6.02 & 5.69 & 5.68 \\
\hline
\end{tabular}

of lactation at classification. The model included herdyear-season, age at calving, and stage of lactation. Age at calving was divided into 9 monthly groups from 22 to 30 mo to allow for a nonlinear relationship between age at calving and TOP. Age at calving was also nested within breed to account for different ages at maturity across breeds. Stage of lactation was divided into 22 groups, $10 \mathrm{~d}$ in length from 0 to $210 \mathrm{DIM}$ and a final group from 210 to 270 DIM. Residuals were standardized within contemporary group (i.e., each residual record was divided by the standard deviation of the respective traits within the respective contemporary group). Standardized residuals were assumed to represent the adjusted TOP records. Each standardized TOP residual was transformed to a qualitative variable with 20 classes: intervals of 0.2 SD between \pm 1 SD, subsequent intervals of $0.5 \mathrm{SD}$ to $\pm 3 \mathrm{SD}$, and 2 final classes of $>|3 \mathrm{SD}|$.

\section{Longevity Data}

Longevity data, including date of birth, date of each subsequent calving, and last known official date recorded (e.g., test-day milk yield record, calving date record, culling date record, mating date record) for each cow were extracted from the national database on the March 15, 2004 on all cows in herds with TOP records; the reason for death or culling was also extracted for cows that died or were culled. Spring calving cows were considered to be right-censored if an official record was available on the cow after June 1, 2003 and the cow subsequently did not die (for any reason) or was not culled; spring calving cows were cows that calved in the last 6 mo of the year. June 1, 2003 was arbitrarily chosen as the start of the most recent spring calving season. Thus, previous spring calving cows not re-calving in spring 2003 were deemed to have been culled. Similar censoring criteria were applied for fall calving cows, except that the cow had to have an official record after January 1, 2003; fall calving cows were cows that calved in the first 6 mo of the year. January 1, 2003 was chosen as the start of the most recent fall calving season; 2003 was chosen rather than 2004 to allow for any possible delay in calving or culling of animals or a delay in the uploading of calving or culling data to the national database. Date of censoring for right-censored animals was the date of data extraction (i.e., March 15, 2004). Reasons for culling were also used to determine whether an animal should be coded as culled or censored. Animals culled because of low production or those moved into unrecorded herds were treated as censored at the time of culling or sale.

Based on the breed composition of the sire and dam, breed heterozygosity and level of heterosis were calculated for each cow (Koch et al., 1985). Breed information is recorded in the database in increments of $1 / 16$ by breed. Breeds included in the database were HolsteinFriesian, Jersey, Ayrshire, Guernsey, Shorthorn, Brown Swiss, and other. A new variable, "breed," was created. Breed was classified as Holstein-Friesian or Jersey for cows at least 13/16 purebred. HolsteinFriesian $\times$ Jersey crossbreds were cows $<13 / 16$ HolsteinFriesian and $<13 / 16$ Jersey, but the sum of the Holstein-Friesian and Jersey proportions was one. Cows not assigned to any of these categories ( $8 \%$ of the data set) were not included in the analysis. The breed composition of the sample population was $54 \%$ HolsteinFriesian, 31\% Jersey, and 15\% crossbred. The propor- 
tion of overseas Holstein-Friesian was also calculated based on all known pedigree and country of origin.

In New Zealand, young test sires receive breeding values for TOP based on daughter performance in sireproving herds; all primiparous cows producing in these herds are type classified. These herds may be considered commercial in nature. Unlike sire-proving herds, for which recording and semen is subsidized, registered herds participate in sire proving on a voluntary basis and receive minimal subsidies. Also, registered herds tend to use a higher proportion of proven sires. Herds coded as registered in the present data set were herds that contained cows that were type classified but were not coded in the database as sire-proving herds. Information on whether the cow resided in a pedigree registered herd or a sire-proving herd was used to separate the cows into 2 herd groups, registered or sire-proving herds; $44 \%$ of cows were from sire-proving herds. In the current study, pedigree registered herds and sireproving herds will be referred to as pedigree herds and commercial herds, respectively. Information on the pedigree registered status of each individual cow was also extracted from the database. In total, $31 \%$ of the cows included in the analysis were registered with either the Holstein-Friesian or Jersey Society in New Zealand, and $46 \%$ of cows in registered herds were themselves not registered with any society. Hence, registered cows were present, along with non-registered cows in sireproving herds; similarly, non-registered cows, along with registered cows, were present in registered herds.

Cows calving for the first time prior to $590 \mathrm{~d}$ of age ( 46 cows) and after $930 \mathrm{~d}$ of age (6830 cows) were removed. Because no information was available on survival prior to first calving, the origin response time was set to age at first calving for each cow. Therefore, longevity in the present study refers to the number of days between date of first calving and date of culling or censoring. Herd-year contemporary groups were created for each cow at each calving. Contemporary groups with $<4$ noncensored records were removed, and the record was coded as censored at the time that the cow entered that contemporary group; $7 \%$ of records were removed with this edit. However, such editing was required to facilitate estimation of the fixed effect for contemporary group in the model of analysis.

Lactation yield deviations for milk, fat, and protein were extracted from the national database for each cowlactation included in the analysis. Lactation deviations were derived as 270-d yields estimated from test-day yields within herd-year-season-age contemporary group (Johnson, 1996). Estimated lactation yields adjust for test-day environment, standardize lactation length, take account of culling, and weights test-day records according to number of tests, stage of lactation at test, and intervals between tests. They are calculated across breed and are expressed on the same base. Each lactation deviation was standardized within contemporary group, which changed at each calving (as had been performed for the TOP traits). Contemporary group was defined as herd-year and was across breeds. Each standardized lactation deviation variable was converted to a class variable with 20 classes: intervals of $0.2 \mathrm{SD}$ between $\pm 1 \mathrm{SD}$, subsequent intervals of $0.5 \mathrm{SD}$ to \pm 3 SD, and 2 final classes of $>|3 S D|$. Thus, standardized lactation deviation variables were available for each lactation of a cow and were used appropriately in the model of analysis as described subsequently. Production values for milk volume, protein yield, fat yield, and live weight (Harris et al., 1996) were extracted from the animal evaluation database for each individual cow. Production values represent the prediction of an animal's future production. It is defined as the sum of the breeding value, non-additive genetic, permanent environment, and average heterosis effects (Harris et al., 1996). Each production value was divided into deciles.

A qualitative variable with 6 classes representing intervals of $15 \mathrm{~d}$ from the start of the calving season was generated for each herd-year; the calving season in New Zealand generally lasts around 12 wk. Each cow received a record for this variable based on her most recent calving relative to the calving season in that herd-year. Thus, this variable represents the time of calving of an animal relative to the start of the calving season. This variable will herein be referred to as the calving period of an animal. The proportion of animals calving in each of the classes was $43.7,35.6,15.7,3.9$, 0.9 , and $0.2 \%$, respectively.

Proportion of genes of each breed (i.e., overseas Holstein-Friesian, New Zealand Holstein-Friesian, and Jersey) was converted to a class variable with 11 levels for each breed: $0 \%$ and 10 subsequent levels, each representing 10 percentage-unit increments. Heterosis among crosses was also converted to qualitative variables with 11 levels: $0 \%$ and 10 subsequent levels, each representing 10 percentage-unit increments.

The longevity data were merged with the adjusted TOP data. Cows that had no information on a particular TOP were assigned into a separate class for each trait to facilitate their inclusion in the analysis. In total, 586,469 cows were included in the analysis. The lower number of animals resulting from the merging is attributable to the lower number of animals within the edited longevity data set. Animals might have been edited out of the data set for reasons including a missing fate code or milk production records, not being represented in the 3 breed categories included in the present study, not calving for the first time within the limits set, calv- 
Table 2. Summary statistics for the number of cows and censored or culling times post first calving of Holstein-Friesians (HF), Jerseys (JER), and crossbreds $(\mathrm{HF} \times \mathrm{JER})$ in pedigree herds.

\begin{tabular}{lrrrrrrr}
\hline & \multicolumn{3}{c}{ Censored } & & \multicolumn{3}{c}{ Culled } \\
\cline { 2 - 4 } \cline { 7 - 8 } & HF & JER & HF $\times$ JER & & HF & JER & HF $\times$ JER \\
\hline Cows, no. & 64,465 & 44,952 & 15,961 & & 113,070 & 70,800 & 17,941 \\
Median & 1454 & 1461 & 1432 & & 958 & 1296 & 974 \\
SD & 938 & 936 & 946 & & 878 & 951 & 905 \\
Minimum & 0 & 0 & 0 & & 4 & 6 & 5 \\
Maximum & 5533 & 5500 & 5476 & & 5381 & 5344 & 4995 \\
\hline
\end{tabular}

ing for the first time into a contemporary group with $<4$ non-censored records or aberrations in their data; such animals were recorded as being culled prior to their first calving.

Tables 2 and 3 summarize the survival statistics of the 3 breeds in pedigree and commercial herds, respectively. The proportion of right-censored records was $39 \%$. The average time at censoring for the right-censored records across all data was $1497 \mathrm{~d}$, with a maximum censoring time of $5533 \mathrm{~d}$. The average failure time across all data for uncensored records was $1204 \mathrm{~d}$ with a maximum failure time of $5631 \mathrm{~d}$.

\section{Survival Analysis}

Preliminary analysis was carried out using the Survival Kit V3.0 (Ducrocq and Solkner, 1998) on the shape of the baseline hazard function. The Kaplan-Meier estimator of the survival function and the Nelson-Aalen estimator of the cumulative hazard function revealed that the underlying survival distribution was non-parametric; no effects were included in the model of analysis. Therefore, survival analysis was undertaken using a proportional hazards Cox model (Cox, 1972).

The proportionality of hazards across breeds was also determined by estimating the hazard function of each breed separately. The within-breed hazard functions relative to the hazard of the Holstein-Friesian were not parallel, indicating that the hazards were not proportional by breed. Therefore, all breeds were analyzed together with the baseline hazard function stratified by breed. Separate analyses were carried out within registered or commercial herds, except in the development of the model when all animals were included in the analysis.

All parameters were estimated by maximum likelihood using a proportional hazards model fitted in the Survival Kit V3.0 (Ducrocq and Solkner, 1998). The convergence criterion was set at $1 \times 10^{-9}$. The hazard function $\mathrm{h}(\mathrm{t})$ of a cow $\mathrm{i}, \mathrm{t}$ days after first calving was defined as

$$
\begin{aligned}
\mathrm{h}(\mathrm{t}) & =\mathrm{h}_{0}(\mathrm{t})_{\mathrm{m}} \exp \left\{\mathrm{HY}_{\mathrm{l}}+\mathrm{A}_{\mathrm{i}}+\mathrm{H}_{\mathrm{ij}}+\mathrm{P}_{\mathrm{ij}}+\mathrm{TOP}_{\mathrm{il}}\right. \\
& \left.+\mathrm{POC}_{\mathrm{il}}+\mathrm{REG}_{\mathrm{i}}+\mathrm{PV}_{\mathrm{ik}}+\mathrm{M}_{\mathrm{il}}+\mathrm{F}_{\mathrm{il}}+\mathrm{Pi}_{\mathrm{l}}\right\}
\end{aligned}
$$

where

$$
\begin{aligned}
\mathrm{h}_{0}(\mathrm{t})_{\mathrm{m}}= & \text { the baseline hazard function representing } \\
& \text { the aging process stratified by breed m; } \\
\mathrm{HY}_{\mathrm{l}}= & \text { herd-year contemporary group l (class } \\
& \text { variable; time-dependent); } \\
\mathrm{A}_{\mathrm{i}}= & \text { age at first calving of cow } \mathrm{i} \text { (time-indepen- } \\
& \text { dent); } \\
\mathrm{H}_{\mathrm{ij}}= & \text { heterosis effect between crosses } \mathrm{j} \text { of cow } \mathrm{i} \\
& \text { (time-independent); } \\
\mathrm{P}_{\mathrm{ij}}= & \text { proportion of overseas Holstein-Friesian, } \\
& \text { New Zealand Holstein-Friesian, and Jer- } \\
& \text { sey genes in cow } \mathrm{i} \text { (time-independent); } \\
\mathrm{POC}_{\mathrm{il}}= & \text { period of last calving of cow i relative to } \\
& \text { the start of the calving season of contem- } \\
& \text { porary group l (class variable; time-inde- } \\
& \text { pendent); }
\end{aligned}
$$

Table 3. Summary statistics for the number of cows and censored or culling times post first calving of Holstein-Friesians (HF), Jerseys (JER), and crossbreds $(\mathrm{HF} \times \mathrm{JER})$ in commercial herds.

\begin{tabular}{lrrrrrrr}
\hline & \multicolumn{3}{c}{ Censored } & & \multicolumn{3}{c}{ Culled } \\
\cline { 2 - 4 } \cline { 7 - 8 } & HF & JER & HF $\times$ JER & & HF & JER & HF $\times$ JER \\
\hline Cows, no. & 54,048 & 23,926 & 24,035 & & 87,342 & 41,677 & 28,252 \\
Median & 1147 & 1429 & 1116 & & 916 & 981 & 959 \\
SD & 940 & 936 & 923 & & 897 & 908 & 936 \\
Minimum & 0 & 0 & 0 & & 3 & 5 & 3 \\
Maximum & 5498 & 5451 & 5506 & & 5520 & 5298 & 5631 \\
\hline
\end{tabular}


$\mathrm{REG}_{\mathrm{i}}=$ pedigree registry status of cow $\mathrm{i}$;

$\mathrm{PV}_{\mathrm{ik}}=$ production value of cow $\mathrm{i}$ for trait $\mathrm{k}(\mathrm{k}=$ milk volume, protein yield, fat yield, and live weight) (class variable; time-independent);

$\mathrm{M}_{\mathrm{il}}=$ lactation deviation for milk yield of cow $\mathrm{i}$ relative to her contemporary group 1 (timedependent);

$\mathrm{F}_{\mathrm{il}}=$ lactation deviation for fat yield of cow $\mathrm{i}$ relative to her contemporary group 1 (timedependent; and

$\mathrm{P}_{\mathrm{il}}=$ lactation deviation for protein yield of cow i relative to her contemporary group 1 (time-dependent).

The appropriateness of either quantitative or qualitative variables for age at first calving, level of heterosis, proportion of genes of each breed (i.e., overseas Holstein-Friesian, New Zealand Holstein-Friesian, and Jersey), the production values, and the milk, fat, and protein lactation deviations were tested separately in the model; both pedigree and commercial herds were analyzed together for the development of the model only. The production values and lactation deviations explanatory variables were only included in the analysis of functional longevity; longevity prior to adjusting for production values and lactation deviation is termed true longevity in the present study. Production values represent expected future production, and lactation deviations represent current production level with time. Therefore, both variables contribute differently to the model.

Ideally, the significance of each additional fixed effect term in the model should be evaluated based on the sums of squares. However, the Survival Kit does not provide sums of squares; hence, the significance of effects in the model was tested by minimizing the Akaike's information criterion (AIC), which was defined as

$$
\mathrm{AIC}=-2 \log \mathrm{L}+2 \mathrm{p}
$$

where $\log \mathrm{L}=\log$-likelihood, and $\mathrm{p}=$ number of parameters in the model. For example, $\mathrm{p}$ is 20 when lactation deviation is the only variable included in the model as a class variable.

The likelihood ratio test comparing an expanded model (the variable of interest included in the model) with the respective reduced model (the variable of interest not included in the model) was also used. Because all TOP had the same number of degrees of freedom, the magnitude of the change in log-likelihood reflected their influence on longevity. The reference class for each TOP, with solutions set to zero, was class 10 ( $-0.2 \mathrm{SD}$ to 0 ). The relative risk of being culled was calculated as the exponent of the solution for each class and was expressed relative to the reference class, which had a relative culling rate of 1.0. Therefore, a relative culling rate $>1$ indicates a higher risk of culling compared with the reference class; the opposite is true for a relative culling rate of $<1$.

Because of the moderate to strong correlations among some TOP (Cue et al., 1996), the influence of an individual trait on longevity may not be attributable to that trait per se, but may instead be an artifact of its relationship with other TOP. Therefore, a forward stepwise selection procedure was performed to identify the extra information attributable to each trait over and above that already explained by previously included TOP in the model. The stepwise analysis was performed for functional longevity in the commercial herds only. The initial model included all fixed effects except TOP, and at each step, the TOP with the largest reduction in the AIC was sequentially added.

\section{RESULTS}

The mean for all Snell-transformed TOP assessed within each of the 3 breed categories for registered and commercial herds, adjusted for age at calving and stage of lactation at assessment, are summarized in Table 1. Holstein-Friesian cows in registered herds had higher scores than did Holstein-Friesians in commercial herds for all TOP except rump angle; Holstein-Friesian cows in registered herds had higher pins than HolsteinFriesian cows in commercial herds. Jersey cows from registered herds had higher scores than Jersey cows in commercial herds for all traits with the exception of rump angle, legs, front teat placement, and rear teat placement. The standard deviation of the farmer-scored traits across breed and herds varied from 1.42 to 1.53; the average standard deviation for the remaining TOP varied from 0.90 to 0.93 (results not shown).

Figure 1 illustrates the Kaplan-Meier estimator of the survival function for the 3 different breeds across all data. The stepwise appearance of the function represents the impact of changing hazard rates at different ages; because of the strict seasonal calving systems in New Zealand, this essentially represents a parity $x$ stage of lactation interaction.

Including all explanatory effects as class variables fitted the combined registered and commercial data significantly better than treating the effects as linear covariables; similar results were found for both true and functional longevity. The AIC decreased by $>7290$ when any of the lactation deviation variables were included as qualitative variables as compared with being treated as linear covariables. The AIC decreased by 573 when 


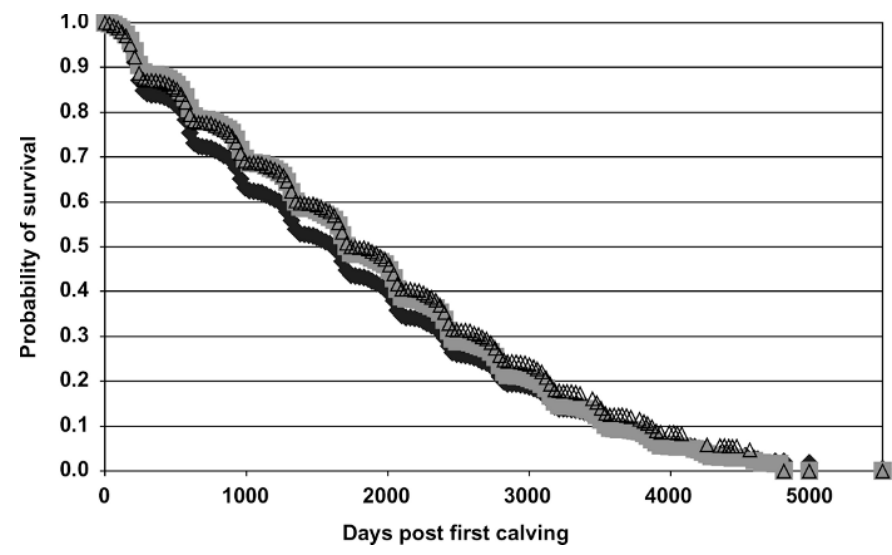

Figure 1. Kaplan-Meier survivor functions for the HolsteinFriesian ( ), Jersey $(\square)$, and crossbred $(\triangle)$ cows in both pedigree and commercial herds combined.

age at calving in the model was altered from a linear regression to a class variable. When the continuous heterosis effect or breed percentage effect was replaced by its discrete form, the AIC decreased by $>60$. Thus, all results reported herein refer to all explanatory effects included in the model as class variables. The estimated effect of contemporary group for functional longevity varied from -0.07 to 0.23 . The risk of culling increased as cows calved later in the calving season. Registered cows had a lower risk of culling than did non-registered cows; the risk of being culled was 47 and $23 \%$ lower for registered cows in registered and commercial herds, respectively. The relative culling rate decreased as production values for milk, fat, and protein yield increased; risk of culling was lowest around the average production value for live weight. The relative culling rate decreased as fat and protein yield deviations increased (Figure 2). Relative culling rate was high in cows with

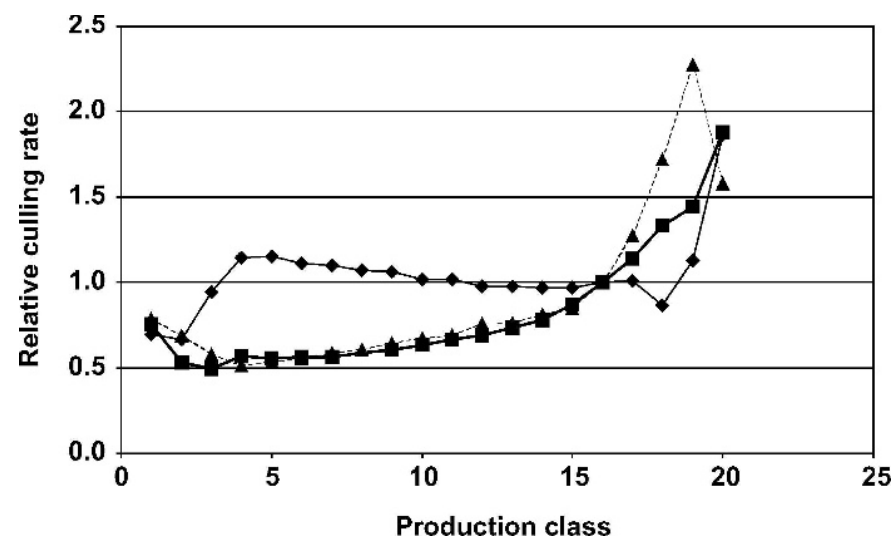

Figure 2. Relative culling rate across different classes of milk production (—-) fat (-口-) and protein (--- $\mathbf{\Delta - - - )}$ yield. extremely low milk yield, low in cows with extremely high milk yield, but relatively constant in between (Figure 2). The risk of involuntary culling increased as the proportion of overseas Holstein-Friesian genes increased, except at high level ( $>80 \%$ overseas) when it decreased again. This result suggests that daughters with a high proportion of overseas genetics may be retained for reasons other than their innate ability to survive. The risk of involuntary culling did not deviate from one as the proportion of Jersey genes in the cow increased.

\section{Registered Herds}

All TOP had a significant $(P<0.001)$ effect on the change in log-likelihood, which was mainly attributed to the large data set. Rump shape (i.e., rump angle and rump width) as well as legs had the largest influence on true longevity (Figure 3). However, the influence of rump shape or legs and the influence of the remaining TOP re-ranked following adjustment for production values and lactation deviations (i.e., functional longevity). Three management traits (adaptability, speed of milking, and temperament) had some of the weakest influence on true longevity; their relative emphasis was increased following adjustment for production values and lactation deviations.

Figure 4 illustrates a decline in relative culling rate as farmer opinion score increases (becomes more desirable). A similar trend of relative culling rate was observed for adaptability, temperament, speed of milking, capacity, udder support, fore udder attachment, rear udder height, udder overall, and dairy conformation. A tendency was observed for the change in relative culling rate to diminish as scores became more favorable. Little difference in relative culling rate was observed following adjustment of longevity for differences in lactation deviation with the exception of cows of extremely poor farmer opinion; the relative culling rates in poor farmer opinion classes were lower following adjustment for milk production values and lactation deviation.

In contrast, an intermediate optimum was observed for legs (Figure 5); cows with an extremely high or low score for legs had a higher risk of being culled. A cow with a legs score of $>2$ SD from the mean had a 15 to $20 \%$ greater chance of being culled compared with a cow with a legs score of -0.2 to 0.0 SD. Similar trends were observed for front and rear teat placement and, to a lesser extent, for rump angle and rump width.

The trend of culling risk was similar across all TOP scores, regardless of whether the record was adjusted for milk production, with the exception that the relative culling rate of extreme udder-related traits was exag- 


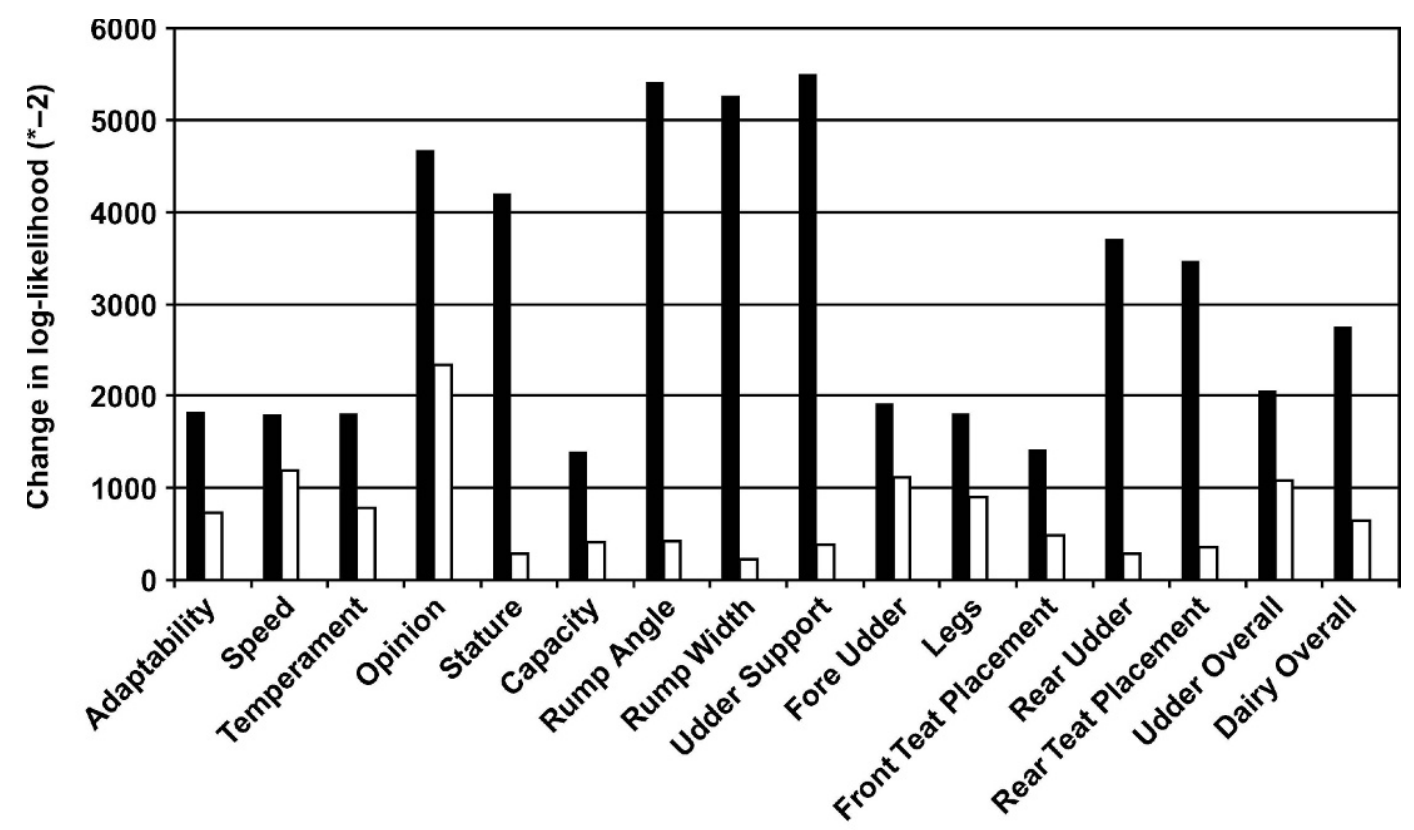

Trait other than production

Figure 3. Contribution of each trait other than production to the change in log-likelihood for true ( $\square$ ) and functional ( $\square$ ) longevity in registered herds.

gerated prior to adjustment for milk production values and lactation deviations.

\section{Commercial Herds}

All TOP had a significant $(P<0.001)$ effect on the change in log-likelihood (Figure 6). Farmer opinion of the cow in first lactation relative to her contemporaries was the most influential of the TOP on true and functional longevity in the commercial herds. The impor-

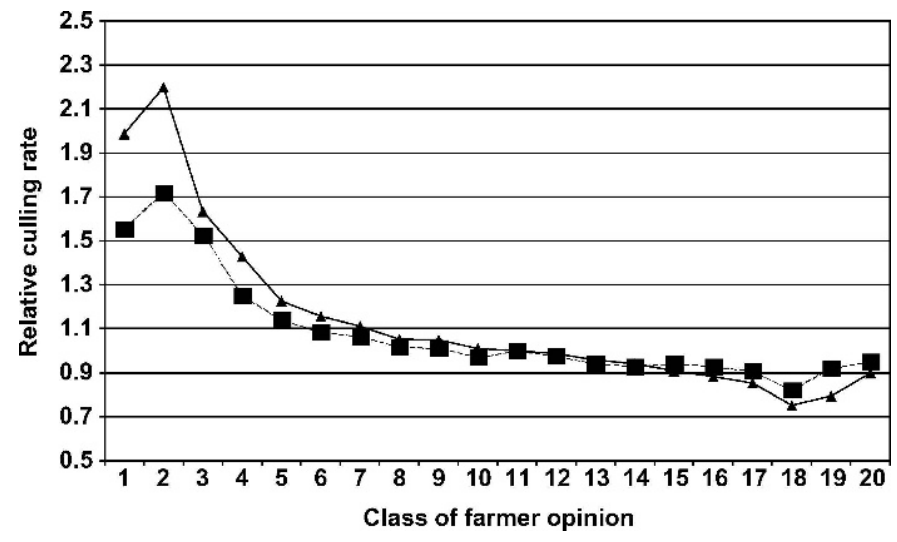

Figure 4. Relative culling rate across different classes of farmer opinion for true (- - ) and functional (----) longevity in registered herds. tance of farmer opinion, relative to other TOP, diminished following adjustment of longevity for the relative milk production of the cow; the change in log-likelihood associated with farmer opinion decreased by 1486 when production values and lactation deviations were included in the model, compared with an average decline of 403 across all other TOP. The influence of the other farmer-scored traits on longevity was similar to those of the classifier-scored traits.

The 2 composite traits (udder overall and dairy conformation) also had large influences on true and func-

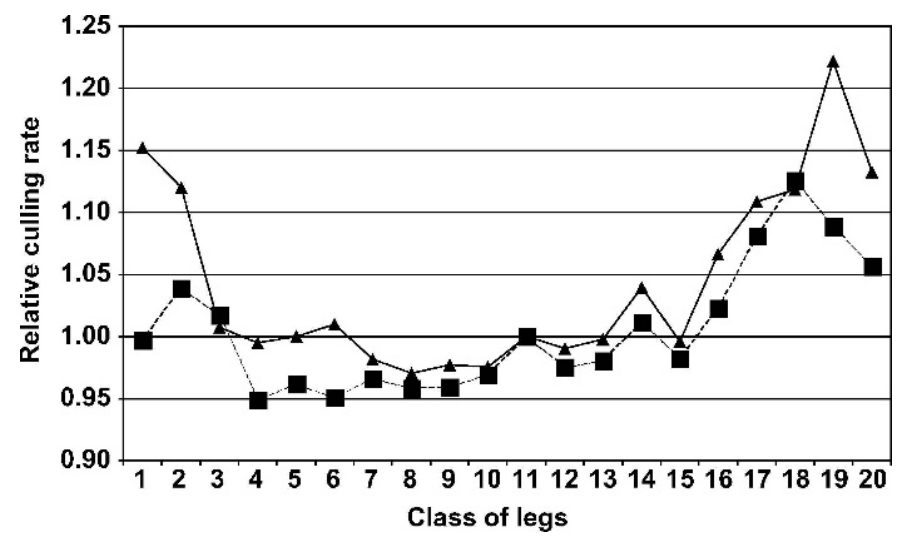

Figure 5. Relative culling rate across different classes of legs for true (- - ) and functional (----) longevity in registered herds. 


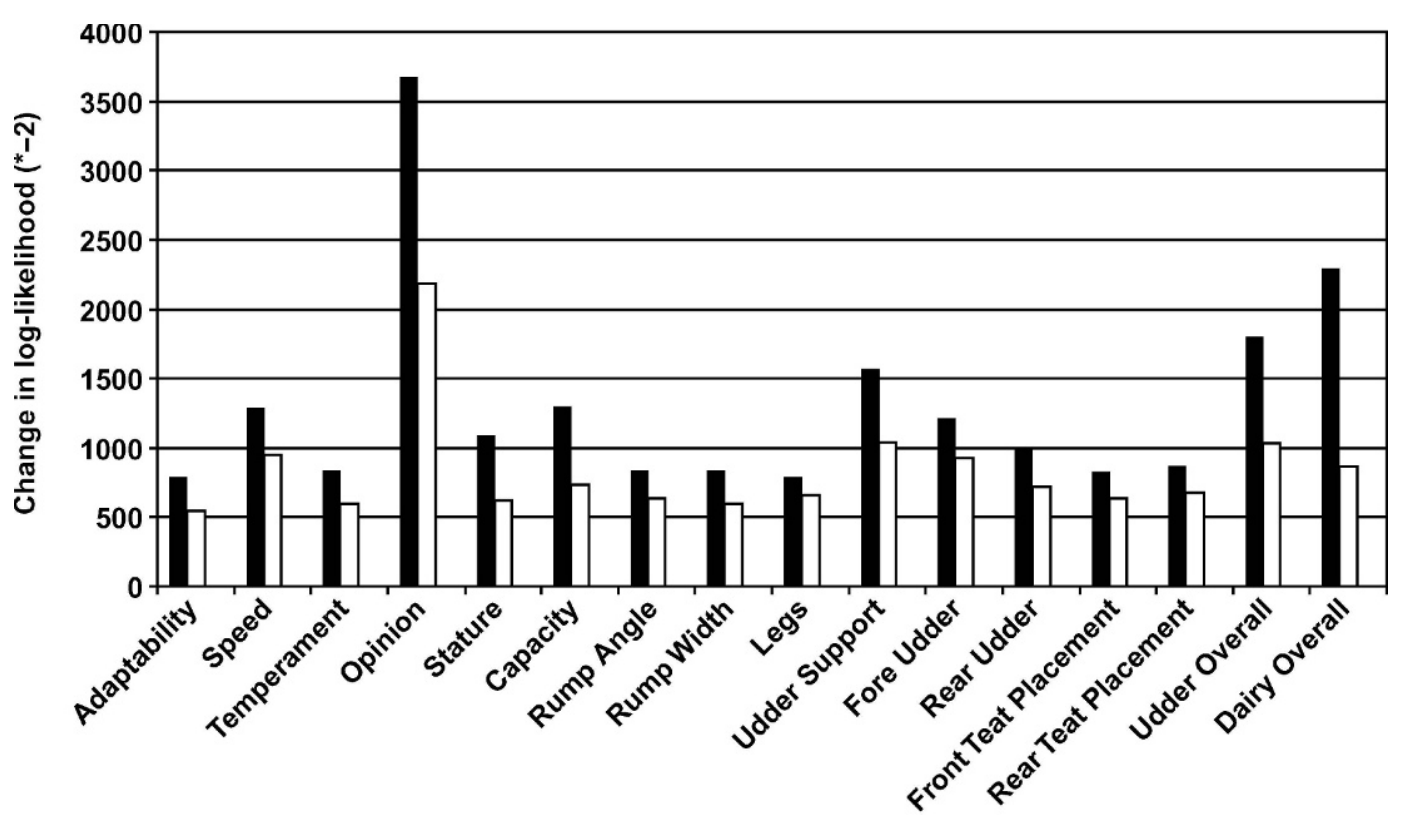

Trait other than production

Figure 6. Contribution of each trait other than production to the change in log-likelihood for true ( $\square$ ) and functional ( $\square$ ) longevity in commercial herds.

tional longevity. Of the individual TOP describing the physical characteristics of the cow, the udder-related traits had the largest effect on functional longevity. Rump shape, legs, and teat placement had the lowest influence on true and functional longevity.

The risk of culling for different classes of farmer opinion is shown in Figure 7. This figure is typical of all 4 farmer-scored TOP, with an observed pattern of diminishing returns as the relative score increased. Cows in the strongly undesirable classes ( $>2$ SD below the mean)

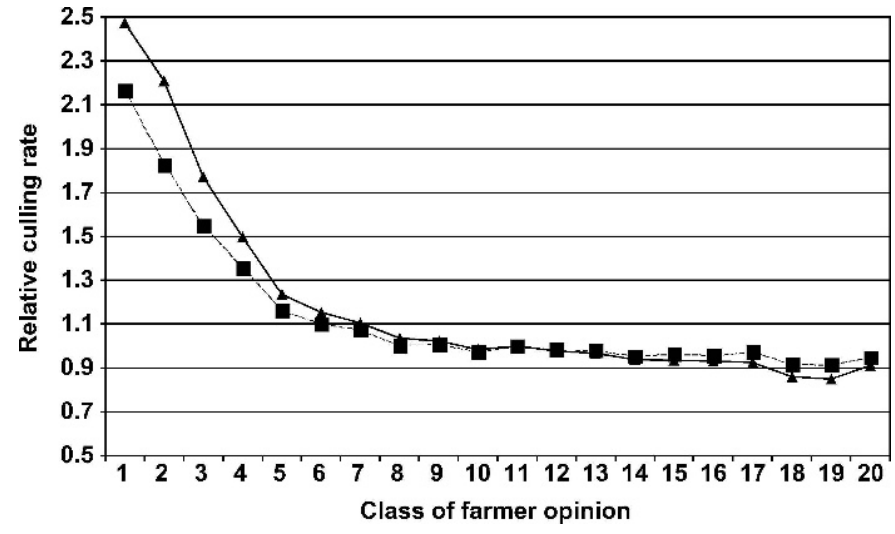

Figure 7. Relative culling rate across different classes of farmer opinion for true (- $\mathbf{\Delta -}$ ) and functional (-- -- ) longevity in commercial herds. were at a higher risk of being culled than were cows with intermediate scores, but cows with high scores appeared to confer no additional advantage in their ability to avoid voluntary and involuntary culling. The risk of culling in the undesirable classes for the farmerscored traits was 1.2 to 2.5 times that of reference class (i.e., -0.2 to $0.0 \mathrm{SD}$ ). As observed in the pedigree herds, little difference in relative culling rates occurred following adjustment for milk production, with the possible exception of a less severe increase in culling risk in cows of poor farmer opinion. The similarity in culling rates is true despite a considerable reduction in the relative importance of farmer opinion on functional longevity.

Based on the relative culling rates for udder overall (Figure 8), cows with a high probability of being culled tended to exhibit lower scores; the same is true for stature, udder support, fore udder attachment, rear udder height, and dairy conformation. Adjustment for milk production values and lactation deviations had little effect on the relative culling rates for these traits with the exception that the relative culling rates of extreme scores was reduced following adjustment for milk production.

Legs showed the opposite trend, with high scoring cows (i.e., more sickled legs) being at greater risk of being culled. This trend was obvious for both true longevity and functional longevity. Capacity, rump angle, 


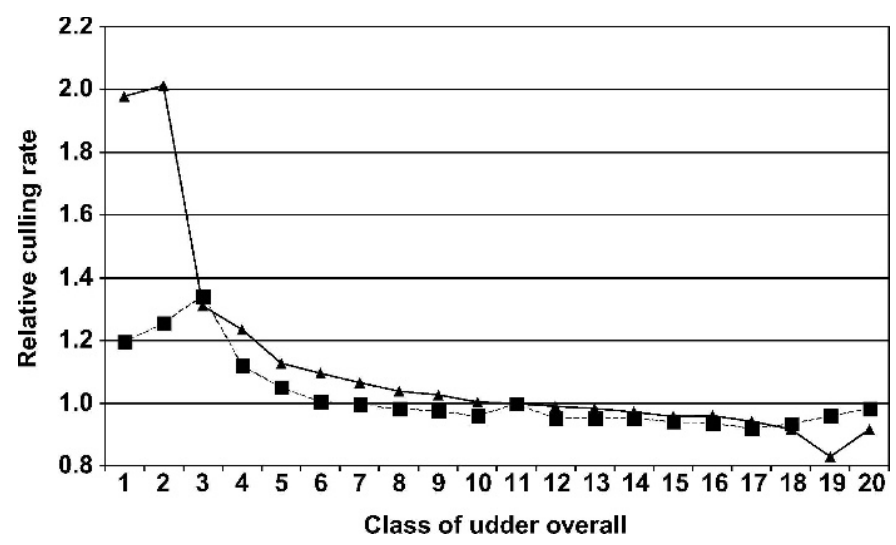

Figure 8. Relative culling rate across different classes of udder overall for true (- $\mathbf{\Delta -}$ ) and functional (--口--) longevity in commercial herds.

rump width, and front and rear teat placement had intermediate optima with an increased risk of being culled in cows at both extremes.

Because of the large size of the data set, each TOP significantly $(P<0.001)$ influenced the change in loglikelihood even with all other fixed effects and TOP previously included in the model. Using a forward stepwise procedure, the $5 \mathrm{TOP}$ to enter the model first were farmer opinion, udder support, udder overall, dairy conformation, and speed of milking, explaining 25, 13, 7, 5 , and $5 \%$, respectively, of the total change in log-likelihood when all TOP were added to the model.

\section{DISCUSSION}

The objective of this study was to investigate the phenotypic relationships between TOP and longevity in New Zealand purebred and crossbred Holstein-Friesian and Jersey dairy cattle. Little international research has been undertaken on the phenotypic relationship between TOP and longevity in commercial herds because of the lack of individual cow phenotypic TOP records in other countries; this is particularly true in pasture-based dairy production systems. Individual TOP phenotypic records were available for cows residing in both pedigree and commercial herds in the present study. Ideally, analysis of functional longevity should incorporate recorded culling reasons, so that one can be sure that functional longevity reflects the innate ability of the animal to avoid involuntary culling. However, recorded culling reasons in the national database were not deemed to be sufficiently accurate to include in the current analysis. Hence, functional longevity in the current study was approximated as true longevity adjusted for cow production values and lactation deviations within contemporary group.
All TOP investigated had a significant influence on true and functional longevity across both herd types. The significance of each TOP may be, in part, caused by the large data set in the present study. There appeared to be contrasting emphasis on the influence of TOP on true longevity depending on whether the cows were in either pedigree or commercial herds. The actual productive life of a cow in registered herds was influenced more by the physical characteristics of the animal, especially rump and leg-related traits, than by management traits. However, following adjustment for relative milk production of the cow, the influence of individual TOP was similar for both herd types.

\section{Management Traits}

The larger standard deviation of the farmer-scored traits compared with the classifier-scored traits (results not shown) indicates a greater tendency for the farmers to use the extreme scores more so than the scores in the middle of the scale. Nevertheless, the mean scores for the farmer-scored TOP were similar to the classifierscored traits. Similar observations were reported by Cue et al. (1996) on a subset of the present data set.

The large effect of farmer opinion on true and functional longevity in both the registered and commercial herds suggests that farmers, even in first lactation, are able to identify cows with a higher probability of being culled for reasons other than production; the average stage of lactation at assessment across all cows was between 90 and $100 \mathrm{~d}$. In New Zealand, the average time from calving to first service is between 75 and $85 \mathrm{~d}$ (Grosshans et al., 1997). Thus, recorded farmer opinion of an animal is likely to be partly influenced by the expression, or lack thereof, of estrus by the respective animal. Previous analysis of TOP data in New Zealand revealed heritability estimates of 0.12 to 0.36 for farmer opinion and moderate to strong genetic correlations (0.51 to 0.93 ) between farmer opinion and the other 3 farmer-scored traits (Cue et al., 1996). Cue et al. (1996) also reported moderate genetic correlations (0.37 to 0.63 ) between farmer opinion and survival to first or second lactation in Holstein-Friesian, Jersey, and Ayrshire cows, which highlights the importance of a trait reflecting farmer opinion as a indicator of the ability of a dairy cow to delay both voluntary and involuntary culling and may suggest its usefulness in other international classification schemes. However, farmer opinion is likely to reflect a conglomerate of traits. This hypothesis was substantiated by the forward, stepwise selection procedure, which estimated that farmer opinion accounted for $25 \%$ of the phenotypic variation of functional longevity explained by all TOP. 
The lack of a difference in relative culling rate between cows of average or high farmer opinion is because culling decisions on farm depend on comparative evaluations with herdmate contemporaries. Thus, as long as the cow avoids being in the category of disliked potential culls, then having a more desirable set of characteristics is, in practice, irrelevant to the culling decision.

\section{Body and Legs Traits}

The relatively low influence of rump-related traits and legs on functional longevity in registered herds is in contrast with Schneider et al. (2003), who reported a large influence of a rump composite and a feet and legs composite on functional herd life in Canadian Holsteins. This could be, in part, due to differences in the definition in the traits across countries, but also to possible differences in the level of these traits across Canada and New Zealand. Larroque and Ducrocq (2001) postulated that the lack of any significant effect of teat length on longevity in French Holsteins when compared with other international studies might be due to the genetic level of teat length in France being at an acceptable level.

In the present study, across the rump and legs traits, an intermediate optimum was preferable, as indicated by a lower relative culling rate; this trend was observed in both registered and commercial herds. Similarly, stature and teat placement (front and rear) had intermediate optima. Such results would suggest that pedigree herds are not selecting for extreme animals across most TOP.

In contrast to most international studies (Caraviello et al., 2003; Schneider et al. 2003), of the traits describing cow morphology, dairy conformation had the largest influence on true longevity in commercial herds. Dairy conformation scored in New Zealand represents all traits pertaining to the dairy conformation of the cow, including the body traits that have been scored, but excluding all udder-related traits. Dairy conformation scored in New Zealand is somewhat different than similarly named traits scored in most other countries (e.g., dairy form). It describes, among others, the "robustness" of the animal; the genetic correlation between dairy conformation and body condition score in first lactation New Zealand dairy cows is 0.40 (J. E. Pryce, unpublished data, 2004). Strong negative genetic correlations were reported between body condition score and dairy form in US Holsteins (Dechow et al., 2004). Within the forward stepwise procedure, dairy conformation was the first body trait to enter the model, accounting for $5 \%$ of the variation in functional longevity explained by all TOP. The importance of dairy conformation declined following adjustment for milk production. This result suggests that cows with high scores for dairy conformation are high producers. However, it also influenced functional longevity in commercial herds, thereby suggesting that cows deemed to be of good dairy conformation also possess a greater ability to delay involuntary culling.

Body traits appear to influence longevity in US and Canadian herds more so than in European herds (Boettcher et al., 1997; Buenger et al., 2001; Larroque and Ducrocq, 2001; Schneider et al., 2003). Based on the results from the present study, the importance of body traits in New Zealand is dependent on the registry status of the herd. Registry status may also be a contributing factor to the differences across countries, as well as the differential in direct emphasis attributed to type traits in many national breeding objectives.

The importance of the rump traits as indicators of true longevity, especially in pedigree herds, is mainly due to their possible relationship with milk yield as indicated by the reduction in relative importance following adjustment of longevity for differences in milk production. Other possible effects of rump trait on longevity may accrue from their apparent relationship with calving difficulty; cows with wider pins and sloping rumps are reported to have fewer problems associated with calving difficulty (Ali et al., 1984). The large difference in the influence of rump on true or functional longevity in registered herds compared with commercial herds may also suggest increased selection emphasis on milk production in the former. Similar to the present study, Schneider et al. (2003) reported an intermediate optimum for pin setting; cows with extremely high or low pins were at higher risk of being culled. In contrast to the present study, Vollema and Groen (1998) and Schneider et al. (2003) both reported a reduced risk of voluntary culling in Holstein-Friesian cows with wider rumps.

Legs, as measured in New Zealand, is a similar trait to rear legs (side view) or rear legs set reported in some studies (Short and Lawlor, 1992; Larroque and Ducrocq, 2001; Schneider et al., 2003). The low relative importance of legs as an indicator of longevity in the commercial herds agrees with Larroque and Ducrocq (2001), who reported no significant effect of feet and legs traits on true longevity in non-registered Holstein herds. Across both the registered and commercial herds in the present study, a higher risk of culling existed in cows with higher scores for legs (i.e., more sickled); there was a slight tendency for straighter legs to also confer a greater risk of culling. This trend agrees with Schneider et al. (2003), who reported an $80 \%$ higher risk of being culled in Holstein-Friesian cows with extremely curved legs compared with cows with an intermediate score; cows with extremely straight legs had 
a $34 \%$ higher risk of being culled. Similar results were found in Jersey cows (Caraviello et al., 2003).

The system(s) in which cows are managed may have an effect on their linear scores for feet and legs and the subsequent relationship with longevity. The majority of cows in New Zealand are outdoors year round. Fatehi et al. (2003) compared various feet and leg traits across tie stalls and free-stalls and across solid floors and slatted floors. Cows in free stalls had higher phenotypic scores than cows in tie stalls, and cows on solid floors had higher scores than cows on slatted floors. However, they concluded that the extent of genotype-by-environment interaction across environments was not large. Burke and Funk (1993) reported significant differences in regression coefficients for rear legs (side view) on herd life between tie stalls and loose housing and between tie stalls and free-stalls. Differences between cows grazing outdoors year round and cows indoors for a large portion of the year may be even greater. Finally, the standard deviation for legs was one of the lowest of the TOP traits, indicating a reluctance of the classifiers to use the extremes of the scale; this may also influence the relationship between legs and longevity.

\section{Udder Traits}

In agreement with other international literature in Holstein (Short and Lawlor, 1992; Vollema and Groen 1998; Schneider et al., 2003) and Jersey (Caraviello et al., 2003) cows, the udder-related TOP had some of the largest influences on true and functional longevity of the individual conformation traits, especially in cows from commercial herds. Udder overall, which encompasses all udder-related traits, was the most important of the udder traits in the commercial herds; Schneider et al. (2003) reported that of the composite traits (excluding final score, which includes mammary), mammary contributed most to functional longevity. The relative risk of culling consistently decreased as udder overall score increased; this corroborates previous international results on mammary traits (Schneider et al., 2003). Because of the moderate to strong relationship between udder overall and the remaining udderrelated TOP (Cue et al., 1996), the stepwise inclusion of udder support and udder overall in the model precluded a large influence of the remaining udder-related traits on functional longevity in the commercial herds. However, the significance of udder overall in the model, with udder support already included in the model, suggest that their influence on functional longevity is different. Larroque and Ducrocq (2001) reported a somewhat similar result; despite moderate correlations between udder depth and udder cleft, both significantly influenced functional longevity using a forward stepwise procedure.

Of the individual udder traits investigated in the present study, udder support had the largest influence on true and functional longevity in commercial herds. Udder support is sometimes referred to as median suspensory (Schneider et al., 2003), suspensory ligament (Vollema et al., 2000), or udder cleft (Larroque and Ducrocq, 2001), although, in New Zealand, the TOP udder support also includes an element of udder depth relative to the hocks. Udder support has also been shown in other international studies (Vollema et al., 2000; Larroque and Ducrocq, 2001; Schneider et al., 2003) to be one of the most important udder traits in relation to true and functional longevity along with udder texture. These results suggest that cows with healthy udders are better able to withstand the stress of milk production and remain healthy and fertile, thereby persisting in the herd longer. A healthy udder may be defined as tightly attached in front, with good height from the rear and well supported (i.e., a strong median ligament).

A large difference existed in the relative importance of teat placement on true longevity in either registered or commercial herds. This may be attributable to the fact that farmers of the registered herds select more intensely on teat placement to achieve the optimal teat placement. This result corroborates results from Larroque and Ducrocq (2001), who also undertook separate analyses within registered or non-registered herds. They reported a large increase in the influence of teat placement traits on longevity, relative to the other nonudder-related traits, in registered herds compared with non-registered herds. The relative importance of teat placement traits in commercial herds was not as high, indicating that commercial farmers may be inclined to sacrifice poorer than optimal teat placement if the cow excelled in other traits, such as milk production or other TOP.

\section{CONCLUSIONS}

Results from this study indicate a strong association between farmer opinion, scored in first lactation, and longevity. Other farmer-scored traits and udder-related traits were also strongly related to true and functional longevity in commercial herds. Rump and leg-related traits had the strongest influence on voluntary culling for milk production in registered herds; an intermediate score was optimal for these traits. There is a lack of harmony between pedigree and commercial herds on the relative importance of TOP affecting true longevity. Farmers of pedigree herds are placing more emphasis on the conformation of the animal while commercial 
farmers are more likely to cull slow milking cows with poor temperament. This suggests that pedigree breeders should place more emphasis on the management characteristics of an animal to strengthen their positions as providers of superior genetic material to commercial farmers. The results clearly demonstrate the suitability of TOP, especially overall farmer opinion, as phenotypic indicators of the ability of the cow to delay voluntary and involuntary culling. Several traits, most notably legs and teat placement, had intermediate optima with respect to their relationship with culling. The identification of non-linear phenotypic relationships between TOP and longevity question the assumption of linearity between the genetic components of TOP and longevity in genetic evaluations. Thus, further research should be carried out to investigate the possible existence of non-linear genetic relationships among TOP and longevity and how best to account for it in genetic evaluations.

\section{ACKNOWLEDGMENTS}

The authors are grateful to the Irish HolsteinFriesian Association and the Irish Cattle Breeding Federation for financial support of this study. Appreciation is also extended to Vincent Ducrocq for providing use of the Survival Kit software.

\section{REFERENCES}

Ali, T. E., E. B. Burnside, and L. R. Schaeffer. 1984. Relationship between external body measurements and calving difficulties in Canadian Holstein-Friesian cattle. J. Dairy Sci. 67:3034-3044.

Boettcher, P. J., L. K., Jairath, K. R. Koots, and J. C. M. Dekkers. 1997. Effects of interactions between type traits and milk production on survival traits of Canadian Holsteins. J. Dairy Sci. 80:2984-2995.

Buenger, A., V. Ducrocq, and H. H. Swalve. 2001. Analysis of survival in dairy cows with supplementary data on type scores and housing systems from a region of northwest Germany. J. Dairy Sci. 84:1531-1541.

Burke, B. P., and D. A. Funk. 1993. Relationship of linear type traits and herd life under different management systems. J. Dairy Sci. 76:2773-2782.

Caraviello, D. Z., K. A. Weigel, and D. Gianola. 2003. Analysis of the relationship between type traits, inbreeding and functional survival in Jersey cattle using a Weibull proportional hazards model. J. Dairy Sci. 86:2984-2989.

Cassell, B. G., R. E. Pearson, J. Stoel, and S. Hiemstra. 1990. Relationships between sire evaluations for linear type traits and lifetime relative net income for grade or registered daughters. J. Dairy Sci. 73:198-204.

Chirinos, Z., D. Hernandez, and M. J. Carabano. 2003. Relación de caracteres de conformación con longevidad functional en ganado Frisón utilizando técnicas de supervivencia. Rev. Asoc. Interprof. Desarrollo Agrario. ITEA II(Suppl.)516-518.

Cox, D. R. 1972. Regression models and life-tables. J. Royal Stat. Soc. (Ser. B) 34:187.
Cue, R. I., B. L. Harris, and J. M. Rendel. 1996. Genetic parameters for traits other than production in purebred and crossbred New Zealand dairy cattle. Livest. Prod. Sci. 45:123-135.

Dechow, C. D., G. W. Rogers, L. Klei, and T. J. Lawlor. 2004. Heritability and correlations for body condition score and dairy form within and across lactation and age. J. Dairy Sci. 87:717-728.

Dekkers, J. C. M., L. K. Jairath, and B. H. Lawrence. 1994. Relationships between sire genetic evaluations for conformation and functional herd life in daughters. J. Dairy Sci. 77:844-854.

Dentine, M. R., B. T. McDaniel, and H. D. Norman. 1987. Comparison of culling rates, reasons for disposal, and yields for registered and grade Holstein cattle. J. Dairy Sci. 70:2616-2622.

Ducrocq, V., and J. Sölkner. 1998. "The Survival Kit V3.0”, a package for large analyses of survival data. Proc. 6th World Congr. Genet. Appl. Livest. Prod., New England, Armidale XXIII:359-362.

Ducrocq, V., R. L. Quaas, E. J. Pollak, and G. Casella. 1988. Length of productive life of dairy cows. 2. Variance component estimation and sire evaluation. J. Dairy Sci. 71:3071-3079.

Fatehi, J., A. Stella, J. J. Shannon, and P. J. Boettcher. 2003. Genetic parameters for feet and leg traits evaluated in different environments. J. Dairy Sci. 86:661-666.

Geishauser, T., M. Shoukri, D. Kelton, and K. Leslie. 1998. Analysis of survivorship after displaced abomasum is diagnosed in dairy cows. J. Dairy Sci. 81:2346-2353.

Grosshans, T., Z. Z. Xu, L. J. Burton, D. L. Johnson, and K. L. Macmillan. 1997. Performance and genetic parameters for fertility of seasonal dairy cows in New Zealand. Livest. Prod. Sci. 51:41-51.

Harris, B. L., J. M. Clark, and R. G. Jackson. 1996. Across breed evaluation of dairy cattle. Proc. New Zealand Soc. Anim. Prod. $56: 12-15$.

Johnson, D. L. 1996. Estimation of lactation yield from repeated measures of test-day yields. Proc. New Zealand Soc. Anim. Prod. $56: 16-18$.

Koch, R. M., G. E. Dickerson, L. V. Cundiff, and K. E. Gregory. 1985. Heterosis retained in advanced generations of crosses among Angus and Hereford cattle. J. Anim. Sci. 60:1117-1125.

Larroque, L., and V. Ducrocq. 2001. Relationships between type and longevity in the Holstein breed. Genet. Sel. Evol. 33:39-59.

Neerhof, H. J., P. Madsen, V. P. Ducrocq, A. R. Vollema, J. Jensen, and I. R. Korsgaard. 2000. Relationships between mastitis and functional longevity in Danish black and white dairy cattle estimated using survival analysis. J. Dairy Sci. 83:1064-1071.

Rogers, G. W., B. T. McDaniel, M. R. Dentine, and D. A. Funk. 1989. Genetic correlations between survival and linear type traits measured in first lactation. J. Dairy Sci. 72:523-527.

Roxström, A., and E. Strandberg. 2002. Genetic analysis of functional, fertility-, mastitis-, and production-determined length of productive life in Swedish dairy cattle. Livest. Prod. Sci. 74:125-135.

Schneider, M. del P., J. W. Dürr, R. I. Cue, and H. G. Monardes. 2003. Impact of type traits on functional herd life of Quebec Holsteins assessed by survival analysis. J. Dairy Sci. 86:40834089

Short, T. H., and T. J. Lawlor. 1992. Genetic parameters of conformation traits, milk yield, and herd life in Holsteins. J. Dairy Sci. 75:1987-1998.

Snell, A. J. 1964. A scaling procedure for ordered categorical data. Biometrics 20:592-607.

Van Arendonk, J. A. M. 1986. Economic importance and possibilities for improvement of dairy cow herd life. Proc. 3rd World Cong. Genet. Appl. Livest. Prod., Lincoln, NE. 12:95-98.

Veerkamp, R. F., P. Dillon, E. Kelly, A. R. Cromie and A. F. Groen. 2002. Dairy cattle breeding objectives combining yield, survival and calving interval for pasture-based systems in Ireland under different milk quota scenarios. Livest. Prod. Sci. 76:137-151.

Vollema, A. R., and A. F. Groen. 1998. Conformation traits in survival analysis of longevity in dairy cattle. Proc. 6th World Congr. Genet. Appl. Livest. Prod., Armidale, Australia. 23:371-374.

Vollema, A. R., S. van der Beek, A. G. F. Harbers, and G. de Jong. 2000. Genetic evaluation for longevity of Dutch dairy culls. J. Dairy Sci. 83:2629-2639. 